\title{
NATURE-INSPIRED LEADERSHIP - SEEKING HUMAN-TECHNOLOGY-EARTH HARMONY
}

\author{
A.P. Botha ${ }^{1,2 *}$
}

\section{ARTICLE INFO}

\section{Article details \\ Presented at the $31^{\text {st }}$ annual conference of the Southern African Institute for Industrial Engineering (SAllE), held virtually from 5-7 October 2020. \\ Available online 11 Nov 2020 \\ Contact details \\ Corresponding author \\ anthon@technoscene.co.za \\ Author affiliations \\ 1 Department of Engineering and Technology Management, Graduate School of Technology Management, Faculty of Engineering, Built Environment and IT, University of Pretoria, South Africa \\ 2 TechnoScene (Pty) Ltd, South Africa}

\section{ORCID ${ }^{\circledR}$ identifier}

A.P. Botha

https: / /orcid.org/0000-0001-8716-1226

\section{DOI}

http: //dx.doi.org/10.7166/31-3-2431

\section{ABSTRACT}

"Go to the ant, ... consider its ways and be wise!" (Proverbs 6:6). We have progressed using biomimicry to inform our engineering designs and processes. Yet we have learnt very little in finding our inspiration from nature for leading in our complex world. In nature, those species that learn by observing, listening, making sense, internalising, thinking, and resting at the right time, survive and thrive in their environments - on plains, in mountains, in the bush, rivers, oceans, deserts, and the sky. Fight or flight takes place in both nature and business. Challenges are shared in coexistence, patience, perseverance, resilience, and adaptation. Leadership challenges that are emerging in the new world of human and machine coexistence will also be enriched by lessons from nature that inspire new behaviour, that are not conceived in business schools or legacy cultures, but that are flexible, effective, and work efficiently - as natural solutions have done for millennia. We discuss the makings of a conceptual thought model of leadership inspired by nature. It is a starting point to create an awareness of how nature-inspired leadership may be applied. Yet, when modelling anything on nature, one has to realise that all models are simplifications, which means that nature itself, as a complex system, is not fully understood. Our aim should not be to copy nature, but to extract principles from it.

\section{OPSOMMING}

“Gaan na die mier, ... kyk na sy weë en word wys!" (Spreuke 6:6). Ons het baie vooruitgang getoon deur natuurnabootsing te gebruik in ons ingenieursontwerpe en -prosesse. Ons het egter min geleer om ons inspirasie in die natuur te kry om leiers in ons komplekse wêreld te wees. In die natuur is dit die spesie wat leer deur waar te neem, te luister, sin te maak, in te neem, te dink en op die regte tye te rus wat oorleef en floreer in hulle omgewings - op vlaktes, in berge, die bos, riviere, oseane, woestyne en die lug. Veg of vlug gebeur in beide die natuur en in besigheid. Uitdagings word gedeel in saambestaan, geduld, uithouvermoë, veerkragtigheid, en aanpassing. Leierskap uitdagings wat na vore kom in die nuwe wêreld van die saambestaan van mens en masjien word ook verryk deur lesse uit die natuur wat nuwe gedrag inspireer. Hierdie lesse word nie in bestuurskole of kulturele nalatenskap geleer nie, maar in natuurlike oplossings wat vir miljoene jare plooibaar, effektief en doeltreffend is. Ons bespreek die grondslag van ' $n$ konseptuele denkmodel van leierskap wat deur die natuur geïnspireer is. Dit gee ' $n$ beginpunt om ' $n$ bewustheid te skep van hoe natuurgeïnspireerde leierskap aangewend kan word. Enigiets wat vanuit die natuur gemodelleer word, moet verstaan word teen die agtergrond dat modelle vereenvoudigings is van die werklikheid in die natuur, wat 'n komplekse stelsel is, en dat dit nie ten volle verstaan word nie. Ons doelwit moet nooit wees om die natuur te kopieer nie, maar om beginsels daaruit te onttrek. 
The human being is a learning organism. Our self-perceived superior intellect has made us believe that we know best and, if not, we can learn from our theories, our experience, our places of higher education, and our peers. However, we keep on forgetting to learn from the greatest master who had time to perfect things for millennia - nature. We often overlook the biblical advice to learn from the ants and become wise [1].

Kathleen Allen [2] states that nature is "designed to create conditions conducive to the life of future generations". She indicates that the choice humans have is to be "a part of nature, or apart from nature". Too many of our leadership and management processes today keep us apart from nature.

In engineering, we have succeeded very well in learning from nature. Biologically inspired design, as an emerging field of research, has been successfully used in design thinking and problem-solving [3]. This is also sometimes referred to as biomimicry or biomimetics, which are synonymous. Biomimetics, as described by the International Organisation for Standardisation [4], involves "the application of research and development approaches of interest to practical applications and which use knowledge gained from the analysis of biological systems to find solutions to problems, create new inventions and innovations, and transfer this knowledge to technical systems". Transferring biological principles to technology is the central element of biomimetics. Biomimicry also leads to ideation and ultimately to innovation, resulting in the commercialisation of structures, processes, methodologies, the creation of business, and new markets. It supports human-centred design and systems thinking.

Biomimicry in organisational management has been addressed in the literature [5],[6]; however, it has seen limited application in leadership and management. This is one of the reasons that organisations struggle with sustainable development [7]. Economic and managerial models fail to address sustainable development because they function with an anthropocentric vision. Here human beings are considered the owners of their environment and natural resources are at their disposal. If the paradigm is adopted that everything is part of nature, then the thinking can be widened to ask how nature can help to create sustainability in managing people and economics. Synergising with nature, which has had enough time (3.8 billion years) to optimise its processes and resources, can bring about harmony between people, technology, and the earth. Not enough is done in technology management to recognise this. The company should be viewed as a system, and leaders should then turn to nature to find a measure, model, and mentor [7]. We like to talk about our technological ecosystems, yet we do not equate them to biological ecosystems, where resilience is built in as a result of a fine balance of interdependency and common cause. By using nature as a model, we should learn from it, and not attempt to modify it. We must measure against nature, since it has discovered what works after billions of years of evolution. It should become the de facto standard. By considering nature as a mentor, we fulfil the second part of the biblical advice [1]: “... consider its ways and be wise".

Not only should bio-solutions guide leaders to become more relevant and efficient, but in a complex world, learning from a much wider set of systems (such as galaxies, the weather, and geology) is equally important. The so-called systems mimicry (sytemimicry) is a new way of thinking using not only the biosphere, but nature in its totality - the way all natural systems respond to their environment [8].

Leaders have to take organisations and their people forward in an environment of uncertainty and decisionmaking. There are some principles in living systems that are valuable to understand in leadership [2]. The successful future of an organisation depends on local expertise and self-organisation, and not only on the leader. The problem with leadership today is that "under stress, we regress" [7]. This allows old habits that do not work to surface. Nature tells us that we cannot do it all alone. Nature gives feedback on capacity, control, and problems. Nature operates on interdependence and connectedness. How do we think about our business in the future? There is a much wider spectrum than just sustainability when we learn from nature. This must be evident in the evolution of leadership as well. Current practice is to grow our businesses through degenerative processes, where we degrade our own operating environments through the extraction of resources to maximise and not optimise our returns. We have become aware of a green approach, which is followed by many. The latest aim is sustainability - which does not harm, but is not restoring. Restorative practices take resilience into account. Last, there is regenerative design, where we, like nature, can adapt, develop, and evolve. In this way profit is seen as prosperity in the evolution of the whole system. 
The world that we have built is drastically different from nature. A comparison [9] of human principles and the principles of nature is given in Table 1.

Table 1: Human principles vs nature principles

\begin{tabular}{|l|l|}
\hline \multicolumn{1}{|c|}{ Human } & \multicolumn{1}{|c|}{ Nature } \\
\hline We are over-focusing on growth only & Nature grows as well, but in cycles \\
\hline Our mantra is 'winner takes all' (maximise) & $\begin{array}{l}\text { Nature is also very competitive, but keeps the balance of } \\
\text { the whole (optimise) }\end{array}$ \\
\hline $\begin{array}{l}\text { Being successful is measured in terms of production and } \\
\text { consumption }\end{array}$ & Success is about regeneration \\
\hline We see the world as something to be controlled & Webs of relationships are the most important \\
\hline $\begin{array}{l}\text { The head office is the ultimate power; performance is } \\
\text { dictated }\end{array}$ & There are no head offices, no performance plans \\
\hline Change is managed & Change happens not by pushing, but by making room \\
\hline $\begin{array}{l}\text { Human leadership is about command and control, divide } \\
\text { and rule }\end{array}$ & $\begin{array}{l}\text { Bio-leadership considers finding, connecting, illuminating, } \\
\text { nourishing }\end{array}$ \\
\hline $\begin{array}{l}\text { Approaches of cause and effect hold back the } \\
\text { organisation; the aim is to avoid potentially disastrous } \\
\text { collisions of systems }\end{array}$ & $\begin{array}{l}\text { Emergence guides towards being at ease with not knowing } \\
\text { what will happen if systems collide, but to adapt to what } \\
\text { emerges }\end{array}$ \\
\hline
\end{tabular}

The question is: how should we learn from nature to change our leadership practices? In this paper we look at the different aspects of how we can learn from nature to practise leadership in an increasingly complex and unpredictable world. We present a base for our arguments arising from a literature study, give feedback on a discussion by several business leaders on the topic of nature-inspired leadership, and develop and present a thought model on nature-inspired leadership to assist us in difficult leadership decision-making situations.

\section{LITERATURE REVIEW}

\subsection{Nature and leadership}

To understand what nature-inspired leadership is, we need to look more widely than just biomimicry at the concepts of nature and leadership from a fundamental point of view. A dictionary description of nature is: "The phenomena of the physical world collectively, including plants, animals, the landscape, and other features and products of the earth, as opposed to humans or human creations" [10]. The attributes of nature on which biomimicry focuses [11] are that nature runs on sunlight, uses only the energy it needs, fits form to function, recycles everything, rewards cooperation, banks on diversity, demands local expertise, curbs excesses from within, and taps the power of limits.

Most people know what leadership is. It is guiding, conducting, proceeding, or being foremost among a group of people, called the followers. Leaders influence, motivate, and enable others to contribute to the effectiveness and success of the organisation, community, industry, or country. A vast list of leadership theories exists in the literature [12]. Some of these are: adaptive leadership, autocratic leadership, charismatic leadership, cross-cultural leadership, entrepreneurial leadership, ideological leadership, integrative leadership, laissez-faire leadership, participative leadership, paternalistic leadership, pragmatic leadership, servant leadership, situational leadership, strategic leadership, and transformational leadership. Some of these theories have fallen out of fashion, since they are associated with older versions of the industrial era. Others have survived and, through adaptation, are still relevant. None of them, however, are built on natural phenomena. Leaders also have certain characteristics contained in traits or behaviours. These include emotional intelligence, integrity, self-efficacy, resilience under stress, positive attitudes to authority, a high work ethic, the need for socialised power, extraversion, conscientiousness, agreeableness, low neuroticism, openness, honesty, being forward-looking, inspiring, and high levels of competence.

We humans are learning a lot about leadership evolution as we enter the human-machine partnership era introduced by the Fourth Industrial Revolution (4IR) [13]. In a quest to understand leadership in 4IR, research has been done on the transition from leaders concerning themselves with humans only to leaders being responsible for making humans work with intelligent machines. The transition of leadership from one industrial era to another is an interesting topic for research. Digital leaders have a concern for people, and for innovation and technology. Social leaders focus more on the human aspects, but may neglect the technology part of business. Technological leaders, on the other hand, are often low on social skills. Leadership of diversity, being agile as a leader, and carrying ethical responsibility while being networked 
emerge as leadership qualities that may be most effective in the transition period and in 4IR environments. The new generation of leaders should be aware of the benefits of understanding nature-inspired leadership in an entire holistic ecosystem.

The aim of nature-inspired leadership is not to produce a copy of what is observed, but to extract principles that can be applied in the corporate environment. To understand nature-inspired leadership, one has to establish whether the attributes of nature are aligned with the natural traits of good leaders in the context of the leadership theory that is applied.

\subsection{Biomimicry for leadership}

Leadership and management are not the same. Leaders select talent, motivate, and coach, and indicate the road to a vision, whereas managers plan, evaluate, implement, and execute. Leadership guides management towards a desired destination. Biomimicry and managerial concepts have not been reported on widely in the literature [14]. In their study, Celep, Tunç and Düren [14] put forward propositions in which examples from nature and management synchronise closely. These fit into four major categories: leadership, innovation, strategy, and organisational structure. Some of these are summarised in Table 2, with reference to leadership as a catalyst for good management. Not all examples originate from the study [14]; some have been added by the author.

Table 2 shows that, for each of the actions expected of modern-day leaders, nature has examples to follow. These are at a generic level. To understand the exact leadership approach, one has to look more specifically at the leadership style used in the human and natural worlds.

Table 2: Finding management guidance in nature

\begin{tabular}{|l|l|}
\hline \multicolumn{1}{|c|}{ Leadership requirement } & \multicolumn{1}{c|}{ Lessons from nature } \\
\hline $\begin{array}{l}\text { Establish sustainability - harmonise the } \\
\text { individual and the team }\end{array}$ & $\begin{array}{l}\text { Trees in a forest compete for the same nutrition from the soil, but they } \\
\text { live collaboratively, linked by a network of submerged fungi } \\
\text { (mycorrhizal networks) }\end{array}$ \\
\hline Build flexibility (resilience) & Diverse, decentralised, and distributed ecosystems \\
\hline $\begin{array}{l}\text { Create an environment supportive of } \\
\text { innovation }\end{array}$ & $\begin{array}{l}\text { Redundancy often springs from diversity. When part of a system cannot } \\
\text { accomplish a goal, other parts of the system can accomplish the goal in } \\
\text { different ways }\end{array}$ \\
\hline Establish a creative environment & $\begin{array}{l}\text { In nature, discovery is part of life: scanning, observing, applying the } \\
\text { senses, and evaluating are ongoing activities }\end{array}$ \\
\hline Set strategy & $\begin{array}{l}\text { All living creatures have strategies to survive - as individuals, as a } \\
\text { collective, and as a species }\end{array}$ \\
\hline Harmonise different players & Set the herd on a common course \\
\hline $\begin{array}{l}\text { Being flexible to unexpected problems and } \\
\text { solutions }\end{array}$ & $\begin{array}{l}\text { There is no one best way to survive for all species in nature, since } \\
\text { nature is a flexible system }\end{array}$ \\
\hline $\begin{array}{l}\text { Be ambidextrous - perform differing and } \\
\text { often competing strategic acts at the same } \\
\text { time }\end{array}$ & Fight or flight, or both \\
\hline Provide structure & Form patterns that perform best \\
\hline Using best-of-breed processes & $\begin{array}{l}\text { Nature has no stock or waste }- \text { it is self- producing, just-in-time, and } \\
\text { right-sizes all the time, being lean and self-replicating }\end{array}$ \\
\hline
\end{tabular}

\subsection{Prestige and dominance in leadership}

Van Vugt and Smith [15] use evolutionary synthesis to describe leadership as understood by the biological, social, and cognitive sciences. They state that the literature on leadership has developed independently in these disciplines, and that a synthesis is required to look at parallels. Two leadership styles are addressed: prestige and dominance. These are opposing views on the different functions and expressions of leadership. They are used under certain circumstances. Prestige leaders exercise influence by conferring (or promising to confer) benefits on followers; dominance influences by inflicting (or threatening to inflict) costs on nonfollowers. The prestige-dominance model has been influential in distinguishing the ways in which people (and nature) accumulate status in groups and how followers react. Not all leaders are necessarily highranking individuals, with the result that leadership and status are not identical. Evolutionary theories from nature offer a unifying framework for understanding leadership.

There are different drivers of different leadership styles. Among mammals, leaders gain a direct benefit from their influence on collective behaviour. For example, lactating female zebras initiate group movements most often because of their increased physiological needs (good grass). A pack of hyenas is led by a dominant female. High-ranking female hyenas lead in warfare, because they have the most to gain 
from increasing their territorial boundaries in their female-dominated societies. Kin-related leadership is enforced by lionesses that protect relatives from intruders within their free family groups.

There is a clear distinction between personalised power and positional power. This relates to whether there is respect for the individual or the position the individual holds. Other distinctions in leadership include democratic versus autocratic, and participative versus directive forms of leadership. These are all underwritten by the dual model of prestige and dominance. Charismatic leadership, as a subset of prestige leadership, is described as "a cultural adaptation to induce cooperation among a large group of (genetically unrelated) followers" [15], where the primary intent is to mobilise and expand social networks. Dual leadership models are also prevalent in the wild. It was found [15] that multiple species engage in leadership across a common set of ecological situations: collective movement, food acquisition, intra-group conflict resolution, and inter-group interactions (peaceful or hostile). Leadership styles in nature also vary across domains. Prestige styles mostly emerge during collective movements and foraging. In this context, one individual simply initiates movement or foraging, and other group members follow the initiator that has become the leader for the moment. Prestige leaders have superior knowledge of physiological requirements (e.g., the lactating zebra mares mentioned above). It is for this reason that reproductive or postreproductive females often lead group movement. In contrast to this, physical power, strength, aggression, and dominance strongly predict leadership styles during intra- and inter-group conflicts. Males are particularly likely to lead in this latter context. Natural selection, as a cornerstone of evolution, has enabled mammals to emerge as leaders with attributes reflecting either a dominance or a prestige style. This provides an understanding of the flexible nature of leadership and the dual mode of prestige and dominance. Depending on circumstances, leaders from each group will emerge as required. Sometimes, as in the case of hyenas, the dominant leader can also be the prestige leader, as the alpha female could benefit from both dominance in protecting the pack and prestige leadership in leading by knowledge of the physiological needs of the family. This shows that there are a lot of dynamics in leadership in nature.

\subsection{Everyone is a leader}

The best example of how every unit of a social system can contribute to leadership is flock leadership, as outlined by Will [16]. Humans use it and nature uses it. It recognises the potential for interacting parts of a community or system to self-organise into a coordinated, energised whole leadership role as creating space for the parts to interact while guiding and ingraining the norms of interaction. The harmony that flows from this approach is emergent - meaning that it arises as a result of the interaction of the participants in leadership, and that it is not a pre-understood property of any individual. Note that emergent collective behaviour cannot be commanded and controlled. It is nonlinear and is related to interactions between numerous individuals, and is not the direct result of an authoritarian approach. Influence is driven without formal authority. Interactive leadership like this also drives collective creativity. Nature-inspired emergent collective behaviour is evident in schools of fish, herds of land animals, and flocks of birds. Flocking models consisting of algorithms that reflect the simple movement rules underlying complex aggregate motion have been developed [17]. Collective behaviour has the following attributes: the primary motivation of individuals within the group, the kinds of interactions among individuals, the typical dynamics that result from these interactions, and the characteristic outcomes at the group level. It is found that individual members of a group (a flock) base their action decisions on the behaviours of their peers. An example is a swarm of bees that have to move out of the hive to accommodate population growth. This is accomplished by individual bees communicating locally with one another that the nest is becoming too small. Scouts then explore the area and, back at the hive, communicate the quality of a discovered nesting place through a dance that signals the distance to, and direction of, the new site. The intensity of the dance refers to the quality of the site. This leads to more inspection, and positive feedback leads to consensus to move the swarm. No single individual has an overview of all the different options, but all the information held by individuals contributes to the final decision. This decision is self-organised and determined in a decentralised way. Informative signals are amplified, and white noise is suppressed.

Migrating birds follow a multi-leader system [18]. This is being used in developing algorithms for natureinspired metaheuristics of combinatorial problems. Such problems deal with the finding of a grouping of objects that satisfies given conditions. In a flock of migrating birds, the individuals maintain a relationship pattern. Each individual adds to the solution of the problem (navigation). The individuals share information among themselves that leads to cooperation. The $\mathrm{V}$-formation in bird flight (geese, herons, ibises) has been studied extensively, mostly from the view of energy-saving. The leading bird causes an updraft in its wake, and the following bird uses that to glide rather than flap, thus saving much energy over long migratory trajectories. But this is not the only reason for the V-formation. Birds can see each other more easily and communicate better (the same reason that fighter pilots sometimes assume this formation). In a typical Vformation, the leader bird shares information with the follower birds. The leader bird selects a few random 
neighbour positions. Each time a neighbour has a better solution, it is adopted by the leader. In addition, leader birds are regularly replaced to rest in the formation, rather than to face the full air resistance at the front. This results in follower birds taking leadership positions over the original leader. Follower birds are updated on the best solution from the birds in front of them. It is not only the V-formation that is maintained; clusters of birds and $\mathrm{W}$ - or $\mathrm{J}$-formations are also observed. This shifting of formation points to an adaptability based on collaboration and a dynamic change of the landscape over which the birds fly. This shows self-organisation and cooperation dynamics between leaders based on consensus.

The following, derived from studying migrating birds in nature, pertains to leadership:

- A leader is the bird that has reached the best feasible solution for the group and shares solutions with adjacent birds.

- A follower is a bird that explores solutions from its own view and the information received from the solutions in front of it.

- An independent is a bird that is not currently included in any group of the flock. It does not exchange information with other birds; it generates random neighboursolutions.

The collaborative group structure based on migrating bird formations and communication enhances the diversification of the effort because the leadership role is distributed over the entire space of operation.

\subsection{No-one is a leader}

The flight of a swarm of terns over the ocean, or of quelea finches on the dry semi-desert plains, provides spectacular patterns in the sky. The rapid pace that these birds set, and the quick changes in direction for the whole swarm, are remarkable metaphors for leadership. 'Swarming' usually refers to a collection of animals, birds, insects, or fish that contains units of similar size, motion, and parallel behaviour. From a mathematical modelling perspective [19], [20], swarming reflects emergent behaviour that arises from simple rules that are followed by individuals with no central coordination (no leadership). There are three guiding rules for swarming: elements of the swarm move in the same direction as their neighbours, they remain as close as possible to their neighbours, and they avoid collisions with their neighbours and other objects. Self-organisation of a complex system is demonstrated in these cases. The self-organising behaviour of natural swarms is that of peer-to-peer networks based on algorithms [21]. It is a dynamic and adaptive process in which systems acquire and maintain structures themselves without external control. Swarm intelligence [22] is based on the notion that individual elements follow simple rules, as listed above, that their behaviour is often random, and that interaction between these elements leads to the emergence of intelligent holistic behaviour, unknown to the individual elements of the swarm. Humans also exhibit swarming behaviour. One of the clearest examples is crowd assemblies, where the direction of movement or the 'temperature of emotion' is easily influenced by just being part of the crowd, not by a defined leader. This may lead to unwanted behaviour such as panic buying or stampedes. If swarm behaviour in humans can be developed to produce positive outcomes, no leadership may be required to reach a goal or destination. Swarm behaviour in humans is amplified by social media and hyperconnectivity. The understanding of swarm intelligence in human systems is still very underdeveloped. Violation of one of the simple rules may cause the collapse of beneficial swarming and lead to disaster. It is in swarming intelligence that nature is starting to play a major role in guiding intelligent machine developers to transfer principles of nature to robotics, for example.

\subsection{Path selection}

Path selection in nature depends on the trails left by the predecessors [17]. Ants leave pheromones to guide other ants on the paths that they discover. An ant allows another ant to pick up the scent and follow it to where other ants are going. In this way, the more ants that follow a path, the more pheromones are deposited, and the clearer the path becomes [21]. Where previously left trails are reused a lot, they are reinforced and become the norm. The condition (visibility and decay) of the path being followed determines the motivation for the decision to use it further. Known paths will be connecting destinations in the shortest possible way. However, path networks may exist that effectively combine trails that are available but are not used. New paths are formed when old paths are destroyed, or when an individual breaks out of the norm. This new path is then used increasingly, not by the leader (explorer) forcing followers to do so, but because followers communicate with each other to do so. That means that followers are not always directly following the leader - they also follow followers of the leader. Pragmatism, and not charisma, changes the behaviour of the whole swarm (an ant nest). In complexity thinking terms, an attractor is required to change a path for the better and to break habitual behaviour to instigate new thinking. 
Humans have been attuned often to require structural management and organisational systems with strict hierarchies - to route traffic, allocate tasks and resources, and construct structures that are serviced in many ways. Social insects such as termites, bees, ants, and wasps are fully capable of doing the same tasks without supervision or any method of centralised control. This is enabled through self-organisation and communication that contains positive or negative feedback and iteration.

\subsection{Foraging}

Optimal foraging theory is a behavioural ecology that describes the behaviour of animals when searching for food and consuming it [23]. This is very similar to human leadership in an environment where common markets are shared. Consumption provides the animal with energy, but searching for and capturing the food requires energy and time. To maximise fitness, animals adopt a strategy that provides the most benefit for the lowest cost. Oystercatchers forage on mussels and crack them open with their bills [24]. Different mussel sizes occur, and while large mussels provide more energy than small mussels, large mussels are more difficult to crack open owing to their thicker shells. This means that large mussels have a longer handling time. The 'profitability' of any mussel is weighed up against energy per time of consumption. The oystercatchers must decide which mussel size will provide enough nutrition to outweigh the cost and energy required to open it. This optimisation results in over-foraging not occurring easily in a free nature.

When foraging takes place in an environment where other organisms are also foraging, unique complexities arise. This includes competition and co-habitation. The outcome is shaped by scarcity or abundance. Nature is particularly good at not over-harvesting. It is when boundaries such as fences are put up that overharvesting becomes a real issue. The resources available to each individual are affected, not just by their own behaviour, but also by the simultaneous actions of others. A natural distribution where foragers place themselves in an optimal manner, matching the availability of resources, determines the best flocking options. A foraging group develops a mind of its own. It is when the individuals that comprise a collective (a flock) develop concepts of the collective that the collective builds its own identity. An example is given in the literature [25] of how the decision about resting or foraging is made in a herd of animals. If there is an advantage to foraging together (as zebras and wildebeest do), the equilibrium behaviour of both species becomes highly synchronised. Differences in the energetic reserves of the two species spontaneously develop, leading them to adopt different behavioural leadership roles. The species (or an individual) with lower reserves emerges as the leader who determines when the combined herd should forage. The strategy that gives rise to this behaviour requires no detailed knowledge of the state of the other individuals. When animals forage, they have to make many decisions: to rest or to forage, when to leave a grazing area, and which food items (vegetation) to seek. Their behaviour reflects a trade-off between the risks of starvation and predation, energy reserves to stay or move on, and the environment (the carrying potential of the grazing area). For animals living in social groups, foraging is also complicated by the actions of other individuals or species. It is usually safer to forage at the same time as other members of the group, since there is safety in numbers. How can group members reach a consensus on the timing of foraging sessions? Coordination is resolved through the spontaneous emergence of temporary leaders and followers, guided by differences in energetic state. This outcome of when to move is not the result of a group decision, but emerges from the interaction between individuals who each make their own choices about when to forage or rest, leading to self-organisation.

\subsection{Distributed and connected leadership}

Elephants in nature live in herds under matriarchical leadership, and bull elephants leave these herds and live separately while growing up and when becoming old. The basic family group is the herd. Herds have extended families or social structures called bonds and clans [26]. A second tier of relationships in elephant society is the inter-related bond groups. They forage over large areas, occasionally meeting at watering holes and favourite feeding spots.

This happens when the original foraging spots cannot sustain the larger herd. When resources allow it, elephants may gather in large groups called clans, which consist of different bond groups and families and both female and male herds.

Lyall Watson, in his book Elephantoms [27], writes that elephants live extraordinarily complex lives. Members of a family group do things together; they forage, drink, rest, and travel at the same time. They keep in contact through sight, sound, and touch. They greet each other when groups that are related get together to reinforce old bonds. Mature males live separately, often in small groups or even alone. They are not outsiders, but satellites of the female herds. They keep in touch by sound and smell, to make the whole community real. Elephants communicate over large distances with infrasound. They are always aware of 
what others in the distributed herd are doing, and even the old bulls that do not walk with the herd anymore are connected over distance.

Watson [27] writes: "No elephant can exist alone for long. It is part of a larger whole, a network so diffuse that an extended herd can cover hundreds of square miles. A web of sound connects each part, turning their apparent thin scatter into one great thick-skinned organism." He states that a solitary elephant is not an elephant at all. This is exactly the case where people work with knowledge [28]. Humans can survive on their own knowledge, but will never grow on that only. It is critical to network with other owners of knowledge to set their own knowledge in motion and to let it become effective in individuals and their enterprises. The social structure of elephants resembles a community of practice: they often operate in small groups that have co-existed over a period of time and, through extensive communication, have developed a common sense of purpose and a desire to share survival-related knowledge andexperience.

Elephant herd behaviour has been used to develop an algorithm used in industrial optimisation [29]. A swarm-based meta-heuristic search method, called elephant herding optimisation (EHO), mimics the behaviour of elephant groups [30]. This optimisation algorithm has been found to be very effective in describing complex human-made environments. Leadership in elephant communities can be equated to leading fragmented corporations and multinational presences. Again, the notion of connectedness and constant communication arises as the kingpin of survival and success.

\subsection{Knowing is leading}

Having unique knowledge is usually a driver of leadership in nature. Elephant herds benefit from the memories of old females. An example is given of the parallels between elephant and human leadership where the priority is survival [28]. What do elephants need to know to survive? They need to know where the great rivers are that will supply the herd with water in the dry seasons; the location and 'body language' of predators; the artificial boundaries to movement (fences); the unexpected threat of the 'great hunter', and where the best grazing fields are to ensure that the herd is adequately supplied with the right mix of nutrition. Is this not exactly what is important for the enterprise to survive and thrive, and what human leaders will have to provide? Water as the lifeblood of an enterprise is the streams of new ideas and refreshing input from its knowledge workers. The predators are the competition: where are they, are they presenting a real threat, and when is the charge a mock charge or not? The boundaries are the edges of competencies, as well as the human limitations to business, such as regulations and legislation that hold the enterprise back. The time, weather, and seasons are the right time to launch new products, take new decisions, and act and intervene in the marketplace. The hunter is that unexpected intruder who is watching and stalking, maybe by applying competitive intelligence, and who aims to take the fatal shot at the business. It may also be the acquisition or merger that is looming that looks very lucrative now, but that will kill the leading product, the flourishing innovation, and the team. Last, there are the grazing fields, the markets that will keep the enterprise strong, where a good mix of business, big and small, easy and difficult, can be found. Are the markets large enough to support the expansion of the enterprise? What must be done if sudden droughts befall the enterprise, and where to move to once a market has been saturated (grazed down all the mopanis before they shoot new leaves again)? In humans, age also correlates with leadership in domains that require considerable specialised knowledge and training, but not necessarily in domains that require risk-taking and physical bravery [31].

\subsection{Followership as a choice}

Active leadership occurs in nature, where leaders explicitly signal their intention to others in the group, who can choose to follow or not. Examples are the ants that discover food, and share signals between individuals to lead them from the nest to the food. Migrating honeybee leaders indicate the direction to a new site, and then get support and, through consensus, migrate as a swarm. In both cases there are costs of participating in decision-making, and a limited number take on the role of first followers and coax the bee swarm to follow through rising body temperature and vibration signals. Dolphins with knowledge of the existence of a fish shoal precipitate shifts in the behaviour of the entire group through visual displays, by jumping out of the water and side flop displays. Humans, following global communication signals from leaders - such as priests, politicians, officers in command, or conductors - can beactively led.

\subsection{Evolution of human leadership}

Although one could borrow from nature to understand human leadership, the expansion of the human brain and the increase in human group size that requires leadership indicate major transitions in the evolution of human leadership [31]: 
- $\quad$ Leadership emerged in pre-human species as a mechanism to solve simple group coordination problems, where an individual initiated an action and others followed. Human leadership is not that simple anymore.

- $\quad$ Leadership was meant to initiate collective action in situations involving significant conflicts of interest, where dominant or socially important individuals emerged as leaders.

- $\quad$ Dominance was largely replaced by prestige-based leadership in early human egalitarian societies, which paved the way for democratic and facilitated group coordination.

- $\quad$ The increase in human group size provides new opportunities for leaders to attract followers through manipulation and persuasion.

- The increase in the social complexity of societies (including businesses) that took place after the agricultural revolution produced the need for more powerful and formal leaders to manage complex intra- and intergroup relations.

\section{TESTING THE NOTION OF NATURE-INSPIRED LEADERSHIP WITH LEADERS}

As part of this study, and to verify how leaders perceive the influence of nature on their understanding of leadership, a facilitated discussion session was held with a group of eleven leaders from the private sector. These people represented leadership training, the food industry, entrepreneurship, financial portfolio management, insurance, executive coaching, aerospace systems, spiritual leadership, strategy, and event management.

The main questions debated were: "Can we learn from nature, should we learn from nature, and what, in particular, do we want to adopt from nature in human leadership today?"

There is a strong realisation that humans are part of nature, and that a strong relationship exists between humans and nature. It is not what we can copy from nature, but what we can contextualise through our relationship with nature that can enrich our leadership approaches. The following understanding of natureinspired leadership emerged from the discussion:

- $\quad$ Nature is an important inspiration for leadership, and humans are interconnected with it and are part of nature. We have always learnt from nature, but we must acquire the ability to recognise new lessons from nature to build a better future.

- There is one consciousness in the natural and human worlds; everything is just resonating at different levels.

- It is time to realign human activities with nature to make them more sustainable. The notion of profit should change to prosperity, and that of sustainability to regeneration.

- There must be balance between nature, humans, and technology. Technology has become an intermediary that often separates humans from nature. Using nature-based principles in technology design and application (biomimicry), strengthened by nature-inspired leadership processes, will close that gap.

- Interconnectedness is a core principle in how nature creates harmony. As humans we are connected through spirituality. A larger divinity bonds humans and nature.

- Human systems need a calibration of what is important. Continuous renewal of human value systems is required. We must acquire the ability, like nature, to reset ourselves and our endeavours from time to time. Humans are perpetually restless and ignore seasonality. We need to align with natural cycles for work and rest, and seasons for planting and harvesting, and gain a balanced equilibrium like that of nature.

- We have to realise that, as humans, we are one of the largest changemakers in nature. We think we are only doing harm to nature, but we are also contributing to nature (e.g., through logical conservation).

- The quest for growth should be in breadth and depth. There could be a season for both. How do we use latent energy - as a tree does in wintertime - to resurrect our deep understanding and build breadth in application afterwards?

- The difference in brain structure (the existence of the frontal cortex) between humans and most of the natural species indicates that we can expand our minds through our higher thinking patterns; also as spiritual beings. We should learn from nature not by copying, but by contextual adoption and customisation.

- We should always be mindful as humans of how nature would see us; then we will be able to learn more effectively from nature.

- $\quad$ Different cultures adopt lessons from nature in different ways. It depends largely on self-awareness. 
- $\quad$ Order in nature happens more by instinct and conformance than as a result of ethics. Humans adopt ethics as a guide to order and acceptable behaviour.

- Humans are driven by incentives and have unlimited wants and needs. Nature uses only what it needs for the moment. Human nature is driven more by creating abundance, not by sufficiency. This often leads to overuse and scarcity.

- $\quad$ Humans team up for specific outcomes; nature uses herding as a lifestyle.

- Humans struggle with diversity; nature sees it as bringing a richness to the ecology.

With this understanding of the relationship between nature and humans, we should be in a position to start developing thought models to indicate to us how nature-inspired leadership could work in practice.

\section{A THOUGHT MODEL}

Having learnt something about nature-inspired leadership, it is appropriate now to try to capture it in a model that we can apply in practice. It is a complex environment that needs to be introduced with care. So, it would be good to have a simplified model to interrogate when the switch is made to a new leadership paradigm. Figure 1 shows a conceptual model that needs further development, but that should also be customisable to the particular leadership situation we may find ourselves in.

\subsection{Leadership confrontation}

The process starts with a leader being confronted by a leadership problem, or an opportunity to pursue that requires special attention. Usually, in human-based leadership, the leader will take command of the situation and apply all the good leadership processes acquired over time, supplemented with their ownstyle leadership characteristics. The leader will then fall back on accepted leadership theories to take control of the situation and dictate to followers how to take control (command-and-control).

\subsection{Human solution}

The human leader's solution in a command-and-control mode will be monitored to see whether it exerts the right levels of control over the situation. The solution will be adapted, should there be dynamics at play, by moving up and down between the leader and the follower who has to implement the solutions.

\subsection{Nature equivalent}

Following a nature-inspired route, the leader first asks: what is the equivalent of my problem or opportunity in nature? If an equivalent is found, the two situations are compared. There is thus not an immediate humanonly solution. The equivalent is identified and compared with the problem or opportunity under investigation. The relationship between nature and humans will now support the solution. Leadership in nature has one strong characteristic - connectedness. The leader now looks at who, among other leaders or followers, could be connected and trusted to come up with contributions to the solution. As each contributor adds his or her knowledge and experience, a solution may emerge that could never have been found by individual action alone. This emergence originates from colliding opinions and experiences. However, dictating a solution often avoids such collisions, since conflict can delay solutions.

\subsection{Nature approach}

Once the equivalent in nature has been found by a human leader or leaders, solutions that mimic nature's approach are connected. Now the emergence of the solution is possible, and the context of the solution must be transferred to the human domain by finding the relevance of the path taken. 'Relevance of the solution' refers to its fit in the domain where it will be applied, the impact it will have, and the probability of adoption. The context deals with the applicability of drawing the equivalence in the human and nature domains. 


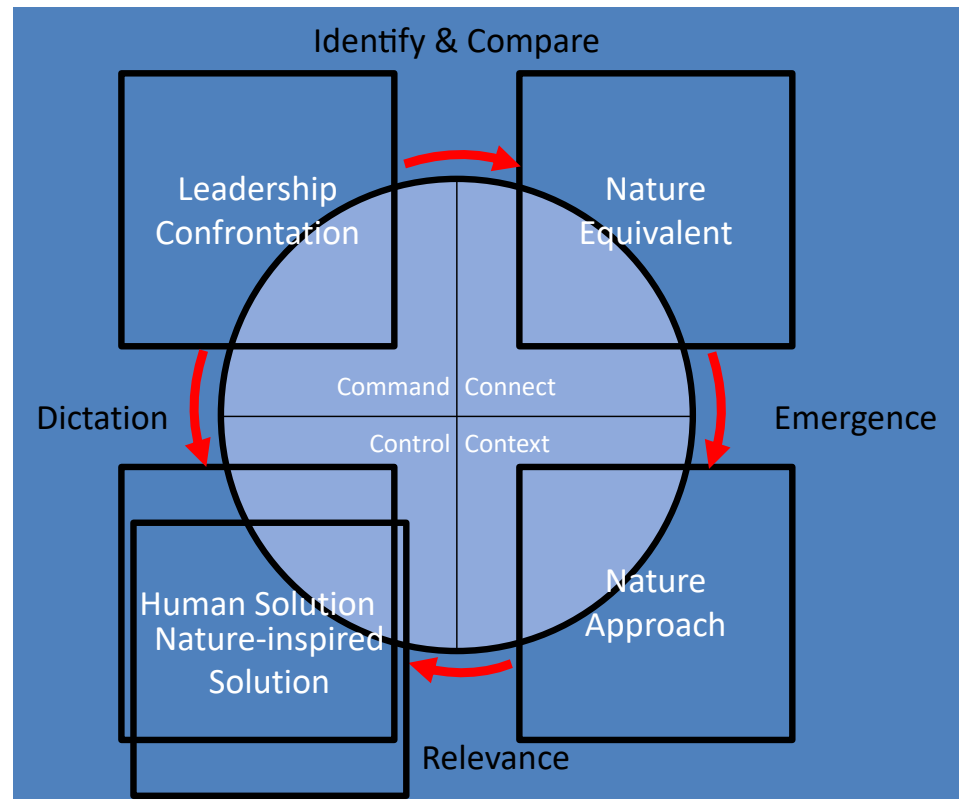

Figure 1: Conceptual thought model for nature-inspired leadership

\subsection{Nature-inspired solution}

Control over the problematic or opportunistic situation is gained more efficiently by following the principles of nature, and adopting the solution is more easily facilitated. Often the human dictation approach may end at sustainability but, as outlined above, restoration (resilience) and regeneration (adaptation and evolvement), following the nature-inspired route, will provide a longer-lasting and more appropriate solution to the whole system that is affected by the problem or opportunity.

Examples are given in Table 3 of how this model may be applied in practical cases of leadership challenges.

Table 3: Comparison of human and nature-inspired leadership approaches to problem-solving

\begin{tabular}{|c|c|c|c|c|c|}
\hline $\begin{array}{c}\text { Problem/ } \\
\text { opportunity }\end{array}$ & $\begin{array}{l}\text { Leadership } \\
\text { confrontation }\end{array}$ & Human solution & Nature equivalent & Nature approach & $\begin{array}{c}\text { Nature-inspired } \\
\text { solution }\end{array}$ \\
\hline Strategy & $\begin{array}{l}\text { Steering } \\
\text { towards the } \\
\text { vision }\end{array}$ & $\begin{array}{l}\text { Leading by } \\
\text { walking ahead } \\
\text { on the path to } \\
\text { the vision }\end{array}$ & $\begin{array}{l}\text { Migratory birds } \\
\text { exchanging } \\
\text { leadership roles }\end{array}$ & $\begin{array}{l}\text { Shared leadership } \\
\text { ensures buy-in }\end{array}$ & $\begin{array}{l}\text { Convincing } \\
\text { followers to move } \\
\text { in the right } \\
\text { direction } \\
\text { themselves }\end{array}$ \\
\hline Competition & $\begin{array}{l}\text { Co-existence in } \\
\text { limited space }\end{array}$ & $\begin{array}{l}\text { Thrive by } \\
\text { elimination of } \\
\text { the weakest }\end{array}$ & $\begin{array}{l}\text { Trees in a forest } \\
\text { connected by } \\
\text { underground } \\
\text { fungal network }\end{array}$ & $\begin{array}{l}\text { Interconnected- } \\
\text { ness allows } \\
\text { essential benefits } \\
\text { for all }\end{array}$ & $\begin{array}{l}\text { Balance needs so } \\
\text { that all can } \\
\text { flourish }\end{array}$ \\
\hline Fragmentation & $\begin{array}{l}\text { Virtuality of } \\
\text { unit of } \\
\text { operation }\end{array}$ & $\begin{array}{l}\text { Consolidation to } \\
\text { bring all units } \\
\text { together }\end{array}$ & $\begin{array}{l}\text { Elephant herd co- } \\
\text { existing over } \\
\text { distance }\end{array}$ & $\begin{array}{l}\text { Communication on } \\
\text { a continuous basis }\end{array}$ & $\begin{array}{l}\text { Operate as a } \\
\text { distributed unit of } \\
\text { operation }\end{array}$ \\
\hline Diversity & $\begin{array}{l}\text { Finding } \\
\text { complements }\end{array}$ & $\begin{array}{l}\text { Forced } \\
\text { collaboration } \\
\text { through rules } \\
\text { and quotas }\end{array}$ & $\begin{array}{l}\text { Zebra and } \\
\text { wildebeest } \\
\text { combining } \\
\text { strengths of vision } \\
\text { and hearing }\end{array}$ & $\begin{array}{l}\text { Sharing best } \\
\text { capabilities }\end{array}$ & $\begin{array}{l}\text { Operating as a } \\
\text { unit based on } \\
\text { supplementary } \\
\text { contributions }\end{array}$ \\
\hline Intelligence & $\begin{array}{l}\text { Environment } \\
\text { scanning and } \\
\text { early warning }\end{array}$ & $\begin{array}{l}\text { Secrecy and } \\
\text { own survival }\end{array}$ & $\begin{array}{l}\text { Baboons on the } \\
\text { lookout, and clear } \\
\text { signalling for all } \\
\text { nearby species }\end{array}$ & $\begin{array}{l}\text { Opportunity (food, } \\
\text { water) and threat } \\
\text { (predator) } \\
\text { sensitivity }\end{array}$ & $\begin{array}{l}\text { Shared survival } \\
\text { and prosperity }\end{array}$ \\
\hline Growth & $\begin{array}{l}\text { Expansion of } \\
\text { unit of } \\
\text { existence }\end{array}$ & $\begin{array}{l}\text { Maximisation of } \\
\text { own effort }\end{array}$ & $\begin{array}{l}\text { Bees scouting for } a \\
\text { new nest }\end{array}$ & $\begin{array}{l}\text { Consensus decision- } \\
\text { making }\end{array}$ & $\begin{array}{l}\text { Optimising } \\
\text { location, space, } \\
\text { and distance for } \\
\text { operations }\end{array}$ \\
\hline
\end{tabular}




\begin{tabular}{|l|l|l|l|l|l|}
\hline $\begin{array}{c}\text { Problem/ } \\
\text { opportunity }\end{array}$ & $\begin{array}{c}\text { Leadership } \\
\text { confrontation }\end{array}$ & Human solution & Nature equivalent & Nature approach & $\begin{array}{c}\text { Nature-inspired } \\
\text { solution }\end{array}$ \\
\hline Profit & $\begin{array}{l}\text { Generating } \\
\text { gains }\end{array}$ & $\begin{array}{l}\text { Resource } \\
\text { depletion }\end{array}$ & $\begin{array}{l}\text { Oystercatchers } \\
\text { deciding on } \\
\text { selecting mussels }\end{array}$ & $\begin{array}{l}\text { Compare energy } \\
\text { gained with time } \\
\text { used for cracking } \\
\text { them open }\end{array}$ & $\begin{array}{l}\text { Optimising } \\
\text { ecosystem gain }\end{array}$ \\
\hline Territory & $\begin{array}{l}\text { Protection of } \\
\text { operating space }\end{array}$ & $\begin{array}{l}\text { Setting } \\
\text { boundaries }\end{array}$ & $\begin{array}{l}\text { Hyena females and } \\
\text { offspring command } \\
\text { line }\end{array}$ & $\begin{array}{l}\text { Kinship-driven } \\
\text { loyalty }\end{array}$ & $\begin{array}{l}\text { Respect for } \\
\text { ownership }\end{array}$ \\
\hline Logistics & $\begin{array}{l}\text { Holism in } \\
\text { operations }\end{array}$ & $\begin{array}{l}\text { Setting standard } \\
\text { operating } \\
\text { procedures and } \\
\text { routes }\end{array}$ & $\begin{array}{l}\text { Ants laying paths } \\
\text { for common action }\end{array}$ & $\begin{array}{l}\text { Integration of } \\
\text { volunteer action }\end{array}$ & $\begin{array}{l}\text { Accumulated } \\
\text { effort by following } \\
\text { the follower }\end{array}$ \\
\hline Change & $\begin{array}{l}\text { Adaptability to } \\
\text { move fast }\end{array}$ & $\begin{array}{l}\text { Introduce } \\
\text { paradigm shifts }\end{array}$ & $\begin{array}{l}\text { Swarming, } \\
\text { changing shape } \\
\text { and direction } \\
\text { rapidly }\end{array}$ & $\begin{array}{l}\text { Allowing space for } \\
\text { change to happen } \\
\text { on emergence }\end{array}$ & $\begin{array}{l}\text { Self-organising } \\
\text { dynamism }\end{array}$ \\
\hline
\end{tabular}

These examples indicate a shift in acceptability and resilience in solutions that are nature-inspired, compared with typical human-dictated solutions based on existing knowledge and leadership theories. There is a shift towards a solution that will be embraced from a nature-centred point of view, with confidence that what has worked for millennia may work again. It is necessary that human leaders and their followers make the shift in mindset to start adopting nature-inspired ways of going about business and life, to ensure more efficient and flexible solutions instead of static solutions that may date soon and be less effective.

\section{CONCLUSION}

When modelling anything on nature, one has to realise that all models are simplifications, which means that nature itself as a complex system is not fully understood. Human leadership is often focused too much on individual control, and not on including other leaders and followers to find solutions. Nature, to a large extent, influences rather than dictates when it comes to leadership. The moment we start viewing our organisations as living systems, leadership gains a different meaning and perspective. Nature-inspired leadership will only be effective if the world that we build becomes more like nature. There may be an argument that change in nature (through evolution) is too slow, and that the fast pace of change in the world, especially technological change, demands faster action. However, when change is built on long-term motivations, such as restoration and regeneration, it provides a firm base for resilience and adaptation. Change in nature is not forced: it is allowed to happen when enough space is given to it. Nature-inspired leadership provides a longer-term view. However, it is not necessarily slow. When a roaming male lion walks into the territory of a pride, the resident male, often joined by the females, knows exactly what to do, and acts fast. Action is based on power, instinctive habit, and a set of natural laws shared by the species. It is often a matter of 'the strongest survive', but very seldom a case of 'the winner takes all'. There is a fine balance between co-existence and termination. There is a saying in business: "You eat what you kill". In nature, there is the knowledge that, to remain eating, you should not kill all the time.

The time has come to invest more effort in learning from nature through biomimicry how to be better leaders, not only from a sustainability point of view, but also to build the most efficient systems that will survive to ensure business for generations to follow. It will be a paradigm shift to make; but the observation of nature has benefitted engineering, construction, new materials, design, and innovation. It has as large a potential to influence leadership. The thought model presented in this paper is a starting point to create an awareness of how nature-inspired leadership may be applied. It has not been tested in practice yet, and should be researched further, with modifications as necessary.

Go to the ant, the bees, the migrating ibises, the elephants, the zebra, the lions, the oystercatchers, the trees, the hyenas, the baboons, the forests ... consider their ways, and be wise!

\section{REFERENCES}

[1] The Bible. Proverbs 6:6, King James Version

[2] Allen, K. 2019. Leading from the roots - Nature inspired leadership lessons. https: / / www.youtube.com/watch?v=5n-3ehyvSzs (accessed August 23, 2020).

[3] Chirazi, J., Wanieck, K., Fayemi, P.E., Zollfrank, C. \& Jacobs, S. 2019. What do we learn from good practices of biologically inspired design in innovation? Applied Sciences, 9(4) p. 650 - 666 
[4] International Organisation for Standardisation) ISO 18458:2015(en) Biomimetics - Terminology, concepts and methodology.

https://www.iso.org/obp/ui/\#iso:std:iso:18458:ed-1:v1:en (accessed May 29,2020).

[5] Tazzi, F. \& de Rossi, C. 2016. Biomimicry in organisations: Business management inspired by nature, $2^{\text {nd }}$ ed. Paris, Kindle edition.

[6] Allen, K. 2018. Leading from the roots - Nature inspired leadership lessons. New York: Morgan James Publishing.

[7] Olaizola, E., Morales-Sánchez, R. \& Huerta, M.E. 2020. Biomimetic organisations: A management model that learns from nature. Sustainability, 12(6), pp. 1-22.

[8] Troncale, L. 2014. Sysinformatics \& systems mimicry: New fields emerging from a 'science' of systems processes engineering. Procedia Computer Science, Conference on Systems Engineering Research (CSER 2014), 28, pp. 663671.

[9] Roberts, A. 2020. How would nature change leadership? TEDxBristol, 2020.

https: / /www.youtube.com/watch?v=PIX-4DJLwRw (accessed June 05, 2020).

[10] Lexico. 2020. Nature. https://www.lexico.com/definition/nature (accessed May 29, 2020).

[11] Lipholt, N. 2019. Biomimicry - Where nature is changing innovation. http://essay.utwente.nl/78549/1/LIPHOLT_BA_bms.pdf (accessed August 26, 2020).

[12] Van der Westhuizen, E. 2020. The relevance of current leadership theories for the Fourth Industrial Revolution. Mini-dissertation (in preparation). University of Pretoria.

[13] Coopasamy, S. 2020. Leadership 4.0: Changes required in leadership within the South African petroleum industry in order to support the Fourth Industrial Revolution. Mini- dissertation (in preparation). University of Pretoria.

[14] Celep, S., Tunç, A.Ö. and Düren, A.Z. 2017. Can biomimicry and managerial concepts come together? Global Business and Management Research: An International Journal, 9(3) pp. 31-46. https://www.researchgate.net/publication/330262085_Can_Biomimicry_and_Manager ial_Concepts_Come_Together (accessed August 26, 2020).

[15] Van Vugt, M. \& Smith, J.E. 2019. A dual model of leadership and hierarchy: Evolutionary synthesis. Trends in Cognitive Sciences, 23(11), pp. 952-967.

[16] Will, T.E. 2016. Flock leadership: Understanding and influencing emergent collective behavior. Leadership Quarterly, 27(2) pp. 261-279.

[17] Goldstone, R.L. \& Gureckis, T.M. 2009. Collective behavior. Topics in Cognitive Science, 1(3) pp. $412-438$.

[18] Lalla-Ruiz, E., De Armas, J., Expósito-Izquierdo, C., Melian-Batista, B. \& Marcos Moreno-Vega, J. 2017. Multileader migrating birds optimisation: A novel nature- inspired metaheuristic for combinatorial problems. International Journal of Bio-Inspired Computation, 10(2), pp. 89-98.

[19] Hedenström, A. \& Åkesson, S. 2016. Ecology of tern flight in relation to wind, topography and aerodynamic theory. Philosophical Transactions of the Royal Society B: Biological Sciences, 371(1704). https://royalsocietypublishing.org/doi/pdf/10.1098/rstb.2015.0396 (accessed August 26, 2020).

[20] Reynolds, C.W. 1987. Flocks, herds, and schools: A distributed behavioral model. Proceedings of the 14th Annual Conference on Computer Graphics and Interactive Techniques, SIGGRAPH 1987, 21(4) pp. 25-34.

[21] Morgan, G. 2016. Biomimicry and its place in business management. https://edepot.wur.nl/418560 (accessed August 23, 2020).

[22] Marcus, L.J., McNulty, E., Dorn, B.C. \& Goralnick, E. 2014. Meta-leadership lessons from the Boston Marathon bombings response. National Preparedness Leadership Initiative. https://cdn1.sph.harvard.edu/wpcontent/uploads/sites/2443/2016/09/Marathon-Bombing-Leadership-Response- Report.pdf (accessed August 26, 2020).

[23] Parker, C.H. \& Hawkes, K. 2018. Optimal foraging theory. The International Encyclopedia of Anthropology. https: //onlinelibrary.wiley.com/doi/abs/10.1002/9781118924396.wbiea2109 (accessed August 26, 2020).

[24] Wikipedia. 2020. Optimal foraging theory. https://en.wikipedia.org/wiki/Optimal_foraging_theory\#Optimal_foraging_of_oysterc atchers (accessed June 7, 2020).

[25] Rands, S.A., Cowlishaw, G., Pettifor, R.A., Rowcliffe, J.M. \& Johnstone, R.A. 2003. Spontaneous emergence of leaders and followers in foraging pairs. Nature, 423(6938), pp. 432-434.

[26] Jabulani Safari Blog, 2020. Elephants and the strength of family - herds, bond groups \& clans. https://jabulanisafari.com/elephants-and-the-strength-of-family-herds-bond-groups-clans/ (accessed 11 Jun. 2020).

[27] Watson, L. 2003. Elephantoms - Tracking the elephant. Johannesburg: Penguin / Random House.

[28] Botha, A.P. 2007. Knowledge - Living and working with it. Cape Town: Juta \& Co.

[29] Elhosseini, M.A., El Sehiemy, R.A., Rashwan, Y.I. \& Gao, X.Z. 2019. On the performance improvement of elephant herding optimization algorithm. Knowledge-Based Systems, 166, pp. 58-70

[30] Li, J., Guo, L., Li, Y. \& Liu, C. 2019. Enhancing elephant herding optimization with novel individual updating strategies for large-scale optimization problems. Mathematics, 7(5), p. 395-430.

[31] King, A.J., Johnson, D.D.P. \& Van Vugt, M. 2009. The origins and evolution of leadership. Current Biology, 19(19), pp. R911-R916. 